\title{
In Defense of Moderate Inclusivism: Revisiting Rawls and Habermas on Religion in the Public Sphere
}

\author{
Jonas Jakobsen* \& Kjersti Fjørtoft**
}

${ }^{\star}$ Department of Philosophy, Faculty of Humanities, Social Sciences and Education UiT The Arctic University of Norway, jonas.jakobsen@uit.no

**Department of Philosophy, Faculty of Humanities, Social Sciences and Education UiT The Arctic University of Norway, kjersti.fjortoft@uit.no

DOI: http://dx.doi.org/10.5324/eip.v12i2.2267

(cc) BY This is an open access article distributed under the terms of the Creative Commons Attribution 4.0 International License, which permits unrestricted use, distribution, and reproduction in any medium, provided the original author and source are credited.

The paper discusses Rawls' and Habermas' theories of deliberative democracy, focusing on the question of religious reasons in political discourse. Whereas Rawls as well as Habermas defend a fully inclusivist position on the use of religious reasons in the 'background culture' (Rawls) or 'informal public sphere' (Habermas), we defend a moderately inclusivist position. Moderate inclusivism welcomes religiously inspired contributions to public debate, but it also makes normative demands on public argumentation beyond the 'public forum' (Rawls) or 'formal public sphere' (Habermas). In particular, moderate inclusivism implies what we call a 'conversational translation proviso' according to which citizens have a duty to supplement religious with proper political arguments if - but only if - they are asked to do so by their co-discussants. This position, we argue, is more in line with the deeper intuitions behind Rawls' political liberalism and Habermas' deliberative model than is the fully inclusivist alternative.

Keywords: conversational translation proviso, deliberative democracy, ethics of citizenship, Habermas, moderate inclusivism, public reason, Rawls

\section{Introduction}

Cultural and religious pluralism is a permanent feature of modern democracies. However, in spite of this diversity of worldviews and ways of life, a stable democracy depends on the citizens' ability and willingness to agree on basic political principles. Thus, in order to make possible an overlapping consensus on 'constitutional essentials' and 'matters of basic justice', Rawls' 'idea of public reason' (IPR) states that members of the 'public forum' (say, judges and lawmakers) should be willing to supplement 'comprehensive' arguments with 'properly political' ones. This means that public officials may present, say, a Christian or Islamic argument about the 
correct interpretation of constitutional principles, but they have a duty to supplement such arguments with other arguments, which do not presuppose the acceptance of any specific worldview - religious or secular. At the same time, Rawls argues that the IPR does not apply in the 'background' culture, say, in public media and civil society.

This paper defends a revised version of Rawls' IPR, which we call moderate inclusivism. Moderate inclusivism distinguishes itself from Rawls' IPR on three accounts. First, it makes moral demands on political argumentation not just in the public forum but also in the 'background culture'. Second, it focuses on debates about legal coercion in general, not just on debates about 'constitutional essentials' and 'matters of basic justice'. Third, and most notably, moderate inclusivism implies what we call a 'conversational translation proviso': We owe our co-deliberators to supplement comprehensive arguments with political ones if - but only if - we are asked to do so by them. Having outlined these basic features of moderate inclusivism, we defend our revised model against Jürgen Habermas' 'asymmetry argument', according to which to the informal public sphere must be fully inclusive in order to equally include religious citizens on fair terms. In a final section, we argue that, on a closer look, Habermas' deliberative model is more in line with moderate inclusivism than with the fully inclusivist alternative, and we point to developments in Habermas' more recent writings, suggesting that he has moved in the direction of moderate inclusivism.

\section{Rawls' idea of public reason}

The motive behind Rawls' reorientation from A Theory of Justice to Political Liberalism was his discovery of the implications of the "fact of reasonable pluralism" for political philosophy (Rawls 2005: xxxvii; also 1987: 1). Whereas Theory relied partly on the moral doctrines of a 'comprehensive liberalism,' Rawls later came to believe that a conception of justice for modern democratic societies must be political in the sense that "there is some hope of its gaining an overlapping consensus in which it is affirmed by the opposing religious, philosophical and moral doctrines" (1987: 1). In order to make such a consensus possible, Rawls argues for certain restrictions on the form and content of public political deliberation. His own interpretation of these restrictions and duties is articulated as an "idea of public reason" (IPR), which reflects our "duty of civility" to other citizens (1997: 769). This duty involves, among other things, "a willingness to listen to others and a fair-mindedness in deciding when accommodations to their views should be reasonably made" (2005: 217). Most notably, it implies that participants in political advocacy attempt to justify their proposals on coercive laws in terms that other citizens can come to accept "as consistent with their freedom and equality" (2005: 218). On this account, political arguments that rely solely and directly on the unquestionable authority of the Bible or on the prophet Mohammad would be considered uncivil because they fail to include citizens with different faiths, philosophies or worldviews.

The IPR applies first to the "public political forum" (1997: 767), by which Rawls refers to the discourse of judges, government officials and candidates for public office. As an ideal, it also applies to ordinary citizens, though "not in the same way, or so strictly" (2005: 215). For citizens, the IPR applies especially when they are voting on fundamental political questions or evaluating candidates for office. In such situations, they are to think of themselves as if they were legislators: "all reasonable citizens think of themselves ideally as if they were legislators following public reason" (1997: 770). 
Rawls also states that the IPR holds for citizens "when they engage in political advocacy in the public forum, and thus for members of political parties and for candidates in their campaigns and for other groups who support them" (2005: 215).

Even though the IPR is not limited to religious doctrines, many critics believe that it wrongly excludes and disadvantages religious citizens. Wolterstorff states, for example, "What Rawls tells me is that if I step outside my own religious community and enter the public debate about the treatment of the poor in our society, I must at no point appeal to my religious convictions" (1997: 172). In a similar vein, Jeffrey Stout argues that Rawls has contributed to a conservative religious backlash against liberalism: "Many religious people have grown frustrated at the unwillingness of the liberal elite to hear them out on their own terms" (Stout 2004: 63). ${ }^{1}$

In order to meet objections like these, Rawls included various forms of 'nonpublic public discourse' in his model of public deliberation, such as "declaration" and "witnessing" (1997: 786-788). 'Declaration' means that citizens declare their (religious or non-religious) comprehensive doctrines to others even though they do not expect others to share them. The aim of doing so is to reassure co-citizens who hold different doctrines that their own doctrine supports the values of a reasonable political conception of justice, and thus to strengthen the "ties of civic friendship" (1997: 786). As examples, Rawls mentions the introduction of religious argumentation in the American civil rights movement and the issue of public support for church schools. 'Witnessing,' on the other hand, refers to situations in which citizens disclose their comprehensive views in order to protest specific institutions, policies or enacted legislation, as when the Quakers express the religious basis of their pacifism (1997: 786). This demonstrates that Rawls considers some types of religious argumentation to be perfectly legitimate, or even desirable, in public deliberation. Many types of religious argumentation are not justificatory but rather explanatory: they explain to others why believers endorse or criticize specific policies or principles, but they do not pretend to be authoritative also for non-believers.

Rawls also responded to inclusivist critics by explaining that the IPR does not apply in what he calls the 'background culture' and the 'public political culture.' When Rawls refers to the background culture he has in mind "churches and associations of all kinds, and institutions of learning at all levels, especially universities and professional schools, scientific and other societies" (1997: 768). Furthermore, the background culture applies to "media of any kind," such as "TV and radio and much else" (e.g., the internet), which are supposed to mediate between the background culture and the "public political culture" (1997: 767):

The idea of public reason does not apply to the background culture with its many forms of nonpublic reason nor to media of any kind. Sometimes those who appear to reject the idea of public reason actually mean to assert the need for full and open discussion in the background culture. With this political liberalism fully agrees (1997: 768).

Within these channels of public communication, Rawls adds, "comprehensive doctrines of all kinds [...] are taught, explained, debated one against another, and argued about, as long as society has vitality and spirit" (Rawls 2005: 383). Given this background, it should be clear that Rawls not only tolerates religious (and other comprehensive) contributions to public debate, but regards them as necessary for the 'vitality and spirit' of modern societies. He also refers to this view as "the wide view of the public political culture" (1997: 783). 
A further response to the inclusivist has to do with the what (the content) of the IPR. Defenders of Rawls have argued that even if the scope (the who) of the IPR is wide in the sense that it includes ordinary citizens engaged in political advocacy, its content is narrow because the proviso applies only to debates about "constitutional essentials and matters of basic justice" (Rawls 1997: 767; also 2001: 90). Constitutional essentials concern questions about basic political rights and liberties; matters of basic justice relate to "questions of basic economic and social justice" (1997: 767). In all others discussions, the IPR does not apply and citizens may refer directly and solely to their comprehensive (secular or religious) doctrines. In this context, Silje Langvatn argues that Rawls is able to keep the balance between the "epistemic virtues" of open and inclusive democratic debate on the one hand, and justice (the equal inclusion of all citizens in public debate) on the other (Langvatn 2016: 145; see also March 2009: 42).

Finally, Rawls made it clear that the point is not to exclude religious reasons in political debates but to supplement them with non-religious political ones. According to his famous 'proviso,' we may "introduce into political discussion at any time our comprehensive doctrine, religious or non-religious, provided that, in due course, we give properly public reasons to support the principles and policies our comprehensive doctrine is said to support" (2005: 453). In other words, Wolterstorff is welcome to state his views about the treatment of the poor in terms of Christian neighborly love or the doctrine of Imago Dei. However, if he advocates a view that involves legal coercion of taxpayers, he should be willing to demonstrate - 'in due course' - how this coercion can also be justified in generally accessible terms (on this point, see also Audi 1997: 140-141).

The question is nevertheless what 'in due course' means at this at point? Must a non-religious reason always follow immediately from a religious one? Must it follow regardless of the form and content of specific arguments? And, is it tenable to say that 'anything goes' when it comes religious argumentation in the background culture, such as in political debates on national television? The following section discusses these and related issues, and suggests a revised version of the IPR.

\section{Moderate inclusivism: revising Rawls}

Rawls' IPR, as presented in the previous section, has led to numerous interpretations, discussions, and criticisms. Habermas (2008), as we shall see, attributes to Rawls an exclusive position that makes it difficult for religious believers to participate as believers in public deliberation. Others, such as Andrew March (2009: 43) and James Boettcher (2009), defend Rawls' IPR by providing a very inclusive reading of it, emphasizing its restricted application and content. In this debate, it is clearly the inclusivist reading that comes closest to the position actually advocated by Rawls. As demonstrated in the previous section, Rawls explicitly states that the background culture, including 'media of all kinds,' is exempted from the IPR and the duty of civility. March therefore argues that it is hard to see how political liberalism limits the depth, scope, and thickness of moral dialogue in the situations in which Habermas [... calls] for it (2009: 43).

We agree with Rawls, for example, that members of churches and nongovernmental associations are not bound as strictly by the IPR as are members of parliament. However, we also believe that a fully inclusivist position on the background culture is in tension with some of the most basic principles in Rawls' 
political liberalism. For example, take the Rawlsian premise that the exercise of political power should ultimately rest on principles that free and equal citizens can be expected to endorse in virtue of their "common human reason" (2005: 137). As a consequence of this premise, Rawls holds that "the public conception of justice is founded on reasonable beliefs that have been established by generally acceptable methods of inquiry" (Rawls 1974: 233-235), and not by appeals to the authority of specific scriptures or prophets. Now, political advocacy in the background culture is clearly one way in which citizens 'exercise political power,' namely by influencing opinions and beliefs on the basis of which other citizens will ultimately cast their vote in local and national elections. Therefore, the refusal to provide a public justification of political views seems to contradict the principle that political power should be exercised through the citizens' common human reason. On a more structural level, such refusal may lead to a situation where a cultural or religious majority continues to reproduce biased majoritarian views that, in turn, influence legislation and political institutions. Such a situation, furthermore, would violate what Rawls calls the 'criterion of reciprocity,' namely that when offering other citizens fair terms of political cooperation, we must also reasonably believe that they could reasonably accept them. He states, "And they must be able to do this as free and equal, and not as dominated or manipulated, or under the pressure of an inferior political or social position" (2005: xlii).

As a consequence of these reservations, we defend a moderate rather than a full inclusivism in the background culture and the public political culture. Attempting to balance between a too restrictive and too wide interpretation of the IPR, our suggestion is to reinterpret Rawls 'proviso' in the following way: we owe it to our codeliberators to use a mutually shareable vocabulary if - but only if - we are asked to do so by them. Put differently, citizens and religious spokespersons may legitimately refer to their comprehensive doctrines as they wish in public debate, and there is no general duty to always supplement comprehensive argumentation with public argumentation. However, when non-comprehensive reasons are explicitly asked for in debates about legal coercion, we have a duty to (attempt to) provide them. We call this the 'conversational translation proviso' because it is triggered in conversation, not as a precondition for conversation. Furthermore, it is a translation proviso in the broad sense that it asks for a non-comprehensive equivalent or 'translation' of the political view advocated.

The conversational translation proviso, we believe, reflects a balance that already characterizes much public debate. If non-believers find a specific example of religious argumentation unproblematic and do not bother to ask for a translation, either because the content is uncontroversial or because the argument is easily translated into a non-religious vocabulary, then the failure to provide a translation will not be labeled as 'uncivil' by the political theorist. At the same time, we can be sure that controversial religious (or otherwise comprehensive) arguments will be challenged in public debate, and that, in these cases, demands for proper political arguments will be raised.

Furthermore, the conversational translation proviso solves a problem with any theory that tries to distinguish between legitimate and illegitimate comprehensive arguments, namely that we often do not know whether an argument is justificatory or merely explanatory (Chambers 2010). Consider for example the following passage from Pope Francis' 2015 speech at the World Meeting of Popular Movements in Santa 
Cruz, Bolivia, in which he addressed problems such as farmworkers without land, families without a home, and laborers without rights:

The Bible tells us that God hears the cry of his people, and I wish to join my voice to yours in calling for land, lodging and labor for all our brothers and sisters. [...]

These are sacred rights. It is [...] well worth fighting for them. May the cry of the excluded be heard in Latin America and throughout the world. ${ }^{2}$

Here, it is not entirely clear whether the Pope implicitly suggests that the Bible is authoritative in political debates, or whether he simply expresses a Christian perspective on social injustice and human rights. Our revised model therefore includes no general prohibition of 'religious reasons,' but merely a duty to continue the conversation when misunderstandings and disagreements related to religious language occur. Through this process, all parties - believers and non-believers - can actively seek a shared discursive universe within which these conflicts can be addressed. Thus, if citizens are in doubt about the intentions of a religious argument (e.g., whether it is justificatory or not), they are free to investigate it and eventually ask for a non-comprehensive translation. On the other hand, the political theorist avoids the danger of excluding arguments as uncivil merely on the suspicion that they are advocatory.

However, the conversational translation proviso needs some further clarifications in order to be fully convincing. First, in our view, the proviso applies to debates about legal coercion in general, and not just to debates about 'constitutional essentials' or 'matters of basic justice' as Rawls would have it. As Habermas puts it, "virtually any controversial legal issue can be heightened into an issue of principle" (Habermas 2008: 123), meaning that any legal controversy might have implications for constitutional issues. Focusing only on constitutional essentials only may therefore give the false impression that the conversational translation proviso applies only to a very limited range of debates, whereas the borders between constitutional debates and other legal debates are in fact much more fluid. As Rawls admits, the IPR applies also in "divisive" legal discussions that "border" on constitutional questions, such as abortion (Rawls 2001: 117). Given the lack of a clear line that separates those issues that border on constitutional essentials from those that do not, this is of little help. The same vagueness applies to Rawls' notion of 'basic justice'. As Ryan argues, "apparently trivial decisions may have an incremental impact on matters of basic justice", such as decisions on the distribution of wealth and income (Ryan 2014: 548). ${ }^{3}$ In our view, therefore, restricting the conversational translation proviso to debates about coercive law gives a consistent response to the problem of vagueness pointed to by Habermas and Ryan: We do not need to discuss if or how a specific legal argument is relevant for constitutional essentials or basic justice; instead, we apply the proviso directly to the argument itself.

Second, moderate inclusivism distinguishes between different types of legal coercion. Calls for the protection of basic rights and social justice, we submit, are different discursive acts than, say, calls for the prohibition of same sex marriage or religious blasphemy. The latter type of argumentation, but not the first, intervenes in a very direct sense in human persons' negative freedom to make their own choices according their own conception of the good. Failing or refusing to obey the conversational translation proviso is therefore a more serious matter, morally speaking, in the latter case than in the first (see also March 2013). 
To illustrate this point, consider again the Pope's appeal to 'sacred rights', cited above. Such generalized appeals to basic rights normally gain the support all around the political spectrum, and rarely cause much disagreement. However, imagine that the Pope's speech were being used by social rights groups to advocate specific legal regulations in specific countries. Imagine also that these regulations were publicly rejected by some citizens in these countries, say, those who believe that taxation aimed at alleviating poverty is a violation of their personal freedom to do as they like with their money. Here, legal coercion and its legitimacy is the topic of public controversy. According to our model, therefore, the conversational translation proviso applies if and only if (a) legal coercion is justified by some citizens directly and solely through a religious vocabulary, and (b) a non-religious translation is explicitly asked for by other citizens. However, the important point is that failing or refusing to obey the conversational translation proviso is not as uncivil in this case as it would be in other cases. The proposed regulations in our example aim at securing basic and commonly acknowledged human goods or capabilities, such as decent working conditions or control over ones material environment. In our view, therefore, refusing to honor the conversational translation proviso in this case might be wrong, but not as wrong as it would have been in other types of debate, namely when basic human freedoms are at stake.

There is, finally, one final difficulty with the conversational translation proviso as formulated so far, namely the unclear status of the concept of a 'conversation'. Does it count as a conversation if one person complaints about politicians' use of religious language on Facebook? Obviously, no one can read and respond to all comments in the mediated public sphere. At the same time, understood as a moral duty, the conversational translation proviso is owed to individuals, qua free and equal. In principle, therefore, any individual can trigger it by asking for a non-religious justification of religious or otherwise comprehensive content. Thus, in order not to make the proviso overly demanding, we shall restrict it to cases where discussants deliberately meet in order to argue with each other, either face to face, say, in public media or parliamentary debates, or indirectly through written exchanges in newspapers or online forums. In such cases, obeying the proviso seems both realistic and fair. Beyond such cases of chosen deliberation, we welcome the attempt to obey the proviso, but we do not regard it as a duty in any moral sense. Or, to put it in a more flexible way: the more a discursive situation resembles that of an actual conversation, the more uncivil is the refusal to obey the conversational translation proviso.

\section{Habermas' asymmetry objection}

Having defended a revised version of Rawls' IPR - moderate inclusivism - the rest of this paper discusses one of Rawls' most influential critics: Jürgen Habermas. The present section looks at Habermas' inclusivist criticism of Rawls, which we, following Yates (2007), refer to as the "the asymmetry objection" (Yates 2007). Given that this objection is intended to show that Rawls is too exclusive, and given that moderate inclusivism is in a certain sense more exclusive than Rawls' original position, it should apply a fortiori to moderate inclusivism. By responding to it, therefore, we aim to defend moderate inclusivism against Habermas' inclusivism.

Habermas agrees with liberals such as Rawls and Audi that the formal institutions of the state (Habermas: the 'formal public sphere') cannot work in a stable and 
legitimate way unless they proceed from a vocabulary that is accessible to all citizens across cultural and religious divides. For this reason, political arguments that rely directly on religious doctrines should be translated into generally accessible ('secular') claims before they are used to justify decisions in parliament, courts, ministries and public administrations. This is known as Habermas' "institutional translation proviso" (2008: 130). However, in his critical revision of Rawls' IPR, Habermas argues that there should be no restrictions on the public use of comprehensive reasons in the 'informal public sphere,' that is, in civil society and public discussions more generally, such as debates in the media or non-governmental organizations. Here, he says, "it is not reasonable to expect Rawls's proviso to apply to those of the faithful who cannot abstain from the political use of 'private' reasons without endangering their religious mode of life" (2008: 131). Thus, given that he, unlike Rawls, allows religious justifications in the informal public sphere, Habermas believes to have articulated a more inclusive and religion-friendly version of the IPR.

Let us first note that Habermas seems to have overlooked Rawls' warning that his 'public forum' is not identical with Habermas' 'informal public sphere': "public reason in political liberalism and Habermas' public sphere are not the same thing" (Rawls 2005: xlviii). Rawls' public forum is a much more restricted sphere, and so restrictions of 'public reasons' in Rawls' sense is not the same as restrictions of the 'public sphere' in Habermas' broad sense. In fact, as we saw, Rawls defends a fully inclusivist position on the 'background culture', including 'media of all kinds'. Thus, as March puts it, "it is hard to see how political liberalism limits the depth, scope, and thickness of moral dialogue in the situations in which Habermas [... calls] for it (2009: 43).

Moderate inclusivism, by contrast, distanced itself from full inclusivism and extended the IPR (in a revised form) beyond the 'public forum'. Habermas' so-called 'asymmetry objection' to Rawls should therefore be even more relevant for moderate inclusivism than for Rawls himself. The asymmetry objection is based on the view that restrictions on religious speech in the informal public sphere imposes an "unreasonable mental and psychological burden" (Habermas 2008: 130) on religious citizens, given "the integral role that religion plays - i.e., its 'seat' - in the life of a person of faith". As Habermas puts it, "genuine faith is not merely a doctrine, something believed, but also a source of energy that the person of faith taps into performatively to nurture her whole life" (Habermas 2008, 127). As he puts it, "[a] devout person conducts her daily existence on the basis of faith. Genuine faith is not merely a doctrine, something believed, but also a source of energy that the person of faith taps into performatively to nurture her whole life" (Habermas 2008: 127). Habermas here accepts a variant of what Mark Jensen calls "the integralist objection to political liberalism" (Jensen 2005: 158), and what Melissa Yates calls the "split identity" objection (Yates 2007: 881). This objection, as articulated by authors such as Wolterstorff and Christopher Eberle, is based on the idea that (some) religious citizens are simply unable to make any kind of distinction between their religious identity and their political viewpoints (Eberle 2002: 145). As Wolterstorff expresses it, "Their religion is not, for them, about something other than their social and political existence" (1997a: 105). Now, the reason why this is an 'asymmetry argument' is the assumption that only believers are burdened psychologically by the duty to translate arguments based comprehensive doctrines into to noncomprehensive arguments. Habermas states, "To date, only citizens committed to 
religious beliefs are required to split up their identities, as it were, into their public and private elements. They are the ones who have to translate their religious beliefs into a secular language before their arguments have any chance of gaining majority support" (2003b: 109, emphasis added). Is it a valid objection to moderate inclusivism and the conversational translation proviso by forcing believers - and only believers to split up their identities in a psychologically painful way?

In our view, the asymmetry objection has been convincingly rejected by other authors, along two different argumentative lines. The first line consists in showing that the inclusivist fear of psychologically burdening the religious individual is exaggerated. Mark Jensen, for example, argues that those believers who deserve protection by the liberal state, i.e., those who already accept the principle of equal freedoms and rights for everyone, are themselves interested in maintaining a religiously neutral political discourse about how this principle is to be understood and implemented (Jensen 2005). Others argue that religious individuals normally have a large reservoir of reasons at their disposal that perfectly fulfill the demands of secular deliberation; reasons that are independent of revealed religious truth-claims, fallible, open to rational examination and comprehensible to a non-religious (or differently religious) audience. Audi, for example, states that controversial issues such as abortion, homosexuality, affirmative action, or periods reserved for prayer or meditation in schools are "easily approached from the points of view of natural law and secular justice" (Audi 1997: 127). Audi's point is not merely that religiously inspired positions on such issues can be stated without relying solely or and directly on revealed doctrines, holy prophets or sacred scriptures, but also that secular reasons are not necessarily alien or external to the identity of the religious citizen. ${ }^{4}$

The other line of argument consists in showing that the religious are not alone in experiencing some amount of frustration or pain when participating in public debates. The reason that Habermas believes secular citizens are not burdened by the ethical requirements of public deliberation has to do with his understanding of secular reasons as being public and shareable by definition: "secular reasons can be expressed in a 'public' or generally shared language" (Habermas \& Taylor 2011: 61). However, by defining secular reasons in this way, he creates the misguided impression that the use of public reasons always comes easily for secular citizens. Why, for example, should we assume that wholehearted Freudians, Hegelians or eliminative materialists do not face some of the same challenges as religious citizens, when asked to formulate their concerns in a generally shareable language? Will such citizens not have to admit that some of their deeply held convictions are too controversial or sectarian to be accepted in political debates about coercive law? Why should non-believers not have 'fundamental beliefs' that are difficult to explain in a commonly accessible language? As Craig Calhoun notes, "[b]oth religious orientations to the world and secular, 'enlightened' orientations depend on strong epistemic and moral commitments made at least partly pre-rationally" (Calhoun 2011: 83).

The reason why Habermas believes that secular citizens are not burdened by the ethical requirements of public deliberation has to do with his understanding of secular reasons as per definition public and shareable: "secular reasons can be expressed in a 'public' or generally shared language" (Habermas \& Taylor 2011, 61). ${ }^{5}$ By defining secular reasons as publicly shareable, he creates the impression that the duty to use a public political vocabulary never conflicts with the 'private' beliefs of 
secular citizens. However, following Calhoun, this impression is clearly misguided: We all need to make some kind of distinction between what we authentically believe to be true, meaningful, beautiful, etc., and what we can reasonably expect others to accept as valid argumentation in political debates.

We shall therefore insist with Rawls that the relevant distinction to draw is not between 'secular' and 'religious' reasons, but between public and non-public ones, given that secular reasons may be just as controversial and sectarian as religious ones: "we must distinguish public reason from what is sometimes referred to as secular reason and secular values. These are not the same as public reason. For I define secular reasoning in terms of comprehensive nonreligious doctrines" (Rawls 2005: 452).

\section{The ethics of citizenship: Habermas as a moderate inclusivist}

So far we have articulated a moderately inclusivist revision of Rawls' IPR and defended this revision against some inclusivist suspicions, as articulated by Habermas. In this final section we aim to demonstrate that on closer inspection, Habermas' own approach is not as inclusive as he presents it. Just like Rawls, Habermas' tendencies towards full inclusivism in the informal public sphere conflicts with other, more basic assumptions in his work. These assumptions, we argue, are in line with moderate inclusivism.

What interests us in this section is "the ethics of citizenship" (2008: 140), which Habermas articulates for civil society and the informal public spheres as an alternative to Rawls' idea of public reason. Habermas' normative conception of citizenship shares Rawls' emphasis on the mutual respect citizens owe one another as free and equal members of a "liberal political culture" (2008: 293). Such membership is based on a legally unenforceable civic solidarity that transcends particular worldviews and ways of life and includes everyone on an equal footing in the process of forming democratic will and opinions. Importantly, the normative expectations that follow from such inclusion imply that "[the citizens] owe one another reasons for their political stances" (2008: 136). Furthermore, a well functioning deliberative democracy presupposes certain attitudes and "political virtues" (2008: 105) on behalf of the citizens, such as the willingness to listen to opponents, to revise one's view in light of convincing evidence or argumentation, to include minorities and marginalized groups, to orient oneself towards the common good and to sometimes "make sacrifices in the common interest" (2008: 105).

As we have seen, Habermas explicitly states that we should not apply Rawls' proviso to the informal domains of public political deliberation. For this reason, most commentators agree with Patrick Neal that Habermas "extends carte blanche to the religious citizen who wishes to advance religious arguments for political positions" (Neal 2014: 324). ${ }^{6}$ If this is true, then Habermas clearly defends a fully inclusivist position with regard to the informal public sphere(s), that is, the 'wild' or 'anarchic' flows of communication that take place outside the formally organized institutions of the state. However, as we shall demonstrate, a more careful reading shows that Habermas' position is much more ambivalent and more moderate than this.

One of the reasons why Habermas is regarded as a full inclusivist in the informal domain is his assertion that "every 'ought' implies a 'can'" (2008: 136), thus implying that religious citizens are incapable of supplementing their comprehensive arguments with publicly accessible ones. As Habermas puts it, we should not confront believers with "normative expectations associated with democratic citizenship" unless a 
"change in mentality" has taken place among the religious (2008: 136). Cathrine Audard therefore believes that Rawls' IPR is normative (about an 'ought') whereas Habermas' ethics of citizenship is descriptive (about a 'can'), and that criticizing an 'ought' with a 'can' is misguided (Audard 2011: 238).

However, the distinction between 'ought' and 'can' is complicated by Habermas' own assertion that "Western culture" has witnessed a "transformation of religious consciousness," which has enabled religious members of this culture to come to terms with the normative requirements of the secular state and to relate to their own truth claims in a "self-reflexive manner (2008: 137). After all, Habermas' view is that we can expect members of 'Western' Judeo-Christian communities of faith to observe the normative expectations associated with democratic citizenship, because "they owe one another good reasons" (2008: 121). This important nuance is missed in Holst and Molander (2015: 553-554), who believe that Habermas regards all religious people as devout in a "totalizing sense", incapable of distinguishing between secular morality and specific doctrines of faith. ${ }^{7}$

Furthermore, given that Habermas' deliberative theory as a whole relies heavily on the formation of transcultural solidarities, mutual respect, and "constitutional patriotism" (1998: 500), we believe that a moderately inclusive position is more in line with his overall approach. As Habermas states, the "unifying bond" (2008: 105) of a well-functioning democracy depends on a "liberal political culture" characterized by "symmetrical relations of reciprocal recognition, including those between the members of different identity groups" (2008: 293). It is difficult to see how such recognition could come about if different identity groups systematically refused to justify their political positions using a vocabulary that transcends their own culturalreligious loyalties.

Consider also the two main reasons why Habermas believes that the formal public sphere must be 'secular.' First, Habermas argues that "[m]ajority rule mutates into repression if the majority deploys religious arguments in the process of political opinion and will-formation and refuses to offer publicly accessible justifications that the outvoted minority, be it secular or of a different faith, can follow and evaluate in the light of shared standards" (2008: 134). We shall call this the risk of repression. Second, in his criticism of Wolterstorff's inclusivism, he argues that the use of religious argumentation in politics introduces a type of conflict into the political system that cannot be solved deliberatively, "at the cognitive level" (2008: 135). This turns political disagreements into religious ones, and "it remains unclear on this [Wolterstorff s] premise why the political community should not be in constant danger of disintegrating into religious conflicts" (Habermas 2008: 135). We call this the risk of antagonistic conflict.

Is there any reason why these two risks are not also present in the informal domains of public deliberation? In our view, we certainly see no reason to assume that these risks somehow disappear when citizens address conflicts, disagreements or controversial topics in mainstream media, social media or other channels of political communication. For example, the majority's insistence on religious language in political disputes may function as a kind of discursive dominance or provoke a spiral of antagonistic conflicts, even though it takes place in the informal sphere. Citizens know that the forms of communication that take place in the informal spheres affect institutionalized politics, and so the insistence on religious justifications by one group is likely to worry other groups or disrupt ties of solidarity and trust in pre-formal 
discursive contexts. This possibility is never considered by authors such as Cecile Laborde (2017: 125) Mave Cooke (2006 \& 2007) and Simone Chambers (2007), all of whom cite Habermas in order to defend the full and unmodified inclusion of religious reasons in the informal public spheres.

Referring to the case of religious pro-life advocates, Chambers argues that Habermas - "in a very un-Rawlsian move" - "laments" their attempt to translate the opposition to abortion into secular terms. On her reading, the problem with such translation is not just its assumed inauthenticity, but more importantly that "meaning is lost" (Chambers 2007: 214). However, in the passage Chambers refers to, Habermas merely says that the translation from a doctrine about the dignity of God-created beings to arguments about the rights of the fertilized ova outside the mother's body is "unfortunate" (2003: 109). This could just as easily mean that he considers the idea that a fetus has human rights to be unconvincing. In any case, we suggest that the risk of repression (and antagonistic conflict) would be very much present if a religious majority would publicly defend the legal prohibition of abortion by appealing solely and directly to religious doctrines and the authority of the Bible or the Quran and refusing to obey the conversational translation proviso. Chambers, by contrast, maintains that there is nothing to worry about as long as believers respect some basic liberal democratic institutions and principles.

Furthermore, in line with Chambers, Habermas is generally positive to the attempts of believers to formulate themselves in terms that transcend particular religious traditions and doctrines. As he puts it, "in this communication [between religious and non-religious citizens], some people's languages are more open, and their reasons more accessible and appealing to wider circles than other people's" (Habermas, Butler, Taylor, West 2011: 115). Habermas admits that 'translation' might not be the best description of this 'encapsulation' of religious meaning, but rather "lifting for the wider public semantic potentials that would otherwise remain lost in the idiom of particular religious doctrines" (Habermas, Butler, Taylor, West 2011: 115).

Finally, there seems to be some evidence that Habermas has revised his position in recent years in the direction of a moderate rather than a full inclusivism:

The neutral character of the 'official language' [...] for formal political procedures $[\ldots]$ is based on a previous background consensus among citizens $[. .$.$] . Without [\ldots]$ such a consensus on constitutional essentials, citizens of a pluralist society couldn't go to the courts and appeal to specific rights or make arguments by reference to constitutional clauses in the expectation of getting a fair decision. How can we settle this background consensus in the first place, if not within a space of neutral reasons [...]. The reasons must be 'secular' [...] (Habermas \& Taylor 2011: 65, emphasis added).

In this passage, Habermas claims that: (a) formalized politics depends on a consensus on constitutional essentials among ordinary citizens in civil society; (b) this consensus can only come about in a political language that is neutral towards competing comprehensive doctrines; and (c) without such as a consensus, citizens will not be able to develop the required degree of trust in their political institutions. Even though we agree with Rawls that 'neutral' is a better term than 'secular,' we welcome Habermas' emphasis on the need for discourses that transcend culture and religion, and agreements also in the informal public sphere. We interpret this as a sign that Habermas has moved closer towards a moderate form of inclusivism. 


\section{Acknowledgements}

We wish to thank three anonymous reviewers for helpful comments and suggestions. In addition, we thank members of the research project Active Citizenship in Culturally and Religiously Diverse Societies (ACT) for valuable discussions of earlier versions of this paper.

\section{Notes}

${ }^{1}$ For inclusivist criticisms of Rawls, se also Cooke 2006, 2007; Eberle 2002; Quinn 1995; Weithman 2007.

${ }^{2}$ Speech downloaded on 20.32017 at http://w2.vatican.va/content/francesco/en/ speeches/2015/july/documents/papa-francesco_20150709_bolivia-movimentipopolari.html

${ }^{3}$ For a similar point, see Wolterstorff 1997a.

${ }^{4}$ See also Døving 2012; March 2013, and Waldron 2012: 855.

${ }^{5}$ For a more detailed analysis of Habermas' understanding of religious versus secular argumentation, see Jakobsen (2017): The Claims of Freedom: Habermas' Deliberative Multiculturalism and the Claims of Free Speech.

${ }^{6}$ For this view, see also Audard 2011; Chambers 2007; Cooke 2006 \& 2007; Holst \& Molander 2015.

7 This, of course, raises complex questions about the status of members of 'nonWestern' traditions, which we cannot pursue at this point.

\section{References}

Audard, C. (2011) "Rawls and Habermas on the Place of Religion in the Political Domain". Rawls and Habermas: Disputing the Political. Routledge.

Audi, R., \& Wolterstorff, N. (1997). Religion in the public square: The place of religious convictions in political debate (No. 94). Rowman \& Littlefield.

Boettcher, J. W. (2009). Habermas, religion and the ethics of citizenship. Philosophy \& social criticism, 35(1-2), 215-238. https://doi.org/10.1177/0191453708098761

Calhoun, C., Juergensmeyer, M., \& VanAntwerpen, J. (Eds.). (2011). Rethinking secularism. OUP USA.

Chambers, S. (2007). How religion speaks to the agnostic: Habermas on the persistent value of religion. Constellations, 14(2), 210-223. https://doi.org/ 10.1111/j.14678675.2007.00434.x

Chambers, S. (2008) “Taking Religion seriously", The Immanent Frame, accessed on 15.42018.

Chambers, S. (2010). Secularism minus exclusion: Developing a religious-friendly idea of public reason. APSA 2010 Annual Meeting Paper. Available at SSRN: https://ssrn.com/abstract=1643852 https://doi.org/10.1353/gso.2010.0010

Cooke, M. (2006). Salvaging and secularizing the semantic contents of religion: the limitations of Habermas's postmetaphysical proposal. International Journal for Philosophy of Religion, 60(1-3), 187-207. https://doi.org/10.1007/s11153-0060006-5 
Cooke, M. (2007). A secular state for a postsecular society? Postmetaphysical political theory and the place of religion. Constellations, 14(2), 224-238. https://doi.org/ 10.1111/j.1467-8675.2007.00435.x

Døving, C. A. (2012). The hijab debate in the Norwegian press: secular or religious arguments?. Journal of Religion in Europe, 5(2), 223-243. https://doi.org/10.1163/ 187489212 X639208

Eberle, C. J. (2002). Religious conviction in liberal politics. Cambridge University Press. https://doi.org/10.1017/CBO9780511613562

Habermas, J. (1994). Struggles for recognition in the Democratic Constitucional State. Multiculturalism: Examining the politics of recongnition. Princeton University Press.

Habermas, J. (1998). Between Facts and Norms. Contributions to a Discourse Theory of Law and Democracy. Massachusetts: The MIT Press.

Habermas, J. (2003). Faith and knowledge. The Future of Human Nature. Cambridge: Polity Press.

Habermas, J. (2008). Between naturalism and religion: Philosophical essays. Polity.

Habermas, J. \& Taylor, C. (2011) Dialogue. The Power of Religion in the Public Sphere. Columbia University Press.

Butler, J., Habermas, J., Taylor, C., \& West, C. (2011). Concluding Discussion. The Power of Religion in the Public Sphere. Columbia University Press.

Holst, C., \& Molander, A. (2015). Jürgen Habermas on public reason and religion: do religious citizens suffer an asymmetrical cognitive burden, and should they be compensated?. Critical Review of International Social and Political Philosophy, 18(5), 547-563. https://doi.org/10.1080/13698230.2015.1021596

Jakobsen, J. (2017). The Claims of Freedom: Habermas' Deliberative Multiculturalism and the Right to Free Speech. Doctoral Thesis, UiT - The Arctic University of Norway. Available at: https://munin.uit.no/handle/10037/10962

Jensen, M. (2005). The integralist objection to political liberalism. Social theory and practice, 31(2), 157-171. https://doi.org/10.5840/soctheorpract200531212

Laborde, C. (2017). Liberalism's religion. Harvard University Press. https://doi.org/ $10.4159 / 9780674981560$

Langvatn, S. A. (2016). Legitimate, but unjust; just, but illegitimate: Rawls on political legitimacy. Philosophy \& Social Criticism, 42(2), 132-153. https://doi.org/10.1177/ 0191453715615386

March, A. F. (2011). Islam and liberal citizenship: The search for an overlapping consensus. Oxford University Press.

March, A. F. (2013). Rethinking religious reasons in public justification. American Political Science Review, 107(3), 523-539. https://doi.org/10.1017/S0003055413000269

Neal, P. (2014). Habermas, Religion, and Citizenship. Politics and Religion, 7(2), 318338. https://doi.org/10.1017/S1755048313000618

Quinn, P. (1995) Politial Liberalisms and Their Exclusions of the Religious. Proceedings and Addresses of the American Philosophical Association Vol. 69, 3556. https://doi.org/10.2307/3130495

Rawls, J. (1974). Reply to Alexander and Musgrave. In S. Freeman (ed.) Collected Papers, 232 - 253. Cambridge University Press. https://doi.org/10.2307/1881827

Rawls, J. (1987). The idea of an overlapping consensus. Oxford J. Legal Stud., 7, 1. https://doi.org/10.1093/ojls/7.1.1 
Rawls, J. (1997). The idea of public reason revisited. The University of Chicago Law Review, 64(3), 765-807.

Rawls, J. (2001). Justice as fairness: A restatement. The Belknap Press.

Rawls, J. (2005). Political liberalism. Columbia University Press.

Ryan, P. (2014). Stout, Rawls, and the Idea of Public Reason. Journal of Religious Ethics, 42(3), 540-562. https://doi.org/10.1111/jore.12069

Stout, J. (2004). Democracy and Tradition: Religion, Ethics, and Public Philosophy.

Taylor, C. (2011) "Why We Need a Radical Redefinition of Secularism". The Power of Religion in the Public Sphere. Columbia University Press.

Waldron, J. (2011). Two-way translation: the ethics of engaging with religious contributions in public deliberation. Mercer L. Rev., 63, 845.

Weithman, P. J. (2007). John Rawls's Idea of Public Reason: Two Questions. JL Phil. \& Culture, $1,47$.

Wolterstorff, N. (1997). Why we should reject what liberalism tells us about speaking and acting in public for religious reasons. Religion and contemporary liberalism, 162. University of Notre Dame Press.

Wolterstorff, N. (1997). The role of religion in decision and discussion of political issues. Religion in the public square: The place of religious convictions in political debate, 67-120.

Yates, M. (2007). Rawls and Habermas on religion in the public sphere. Philosophy \& Social Criticism, 33(7), 880-891. https://doi.org/10.1177/0191453707081685 